\title{
Spatiotemporal Distribution of Potato-Associated Alternaria Species in Wisconsin
}

\author{
Shunping Ding, ${ }^{1,2,3}$ Kiana Meinholz, ${ }^{1}$ and Amanda J. Gevens ${ }^{1, \dagger}$ \\ ${ }^{1}$ Department of Plant Pathology, University of Wisconsin-Madison, Madison, WI 53706 \\ ${ }^{2}$ Wine and Viticulture Department, California Polytechnic State University, San Luis Obispo, CA 93407 \\ ${ }^{3}$ Department of Horticulture and Crop Science, California Polytechnic State University, San Luis Obispo, CA 93407
}

\begin{abstract}
Potato early blight caused by Alternaria solani and potato brown spot caused by Alternaria alternata are two common potato foliar diseases. Fungicide applications in Wisconsin target early blight with the expectation of managing brown spot simultaneously. However, distributions of the two pathogens over time and space have not been previously reported in Wisconsin. In this study, six potato fields in Wisconsin were systematically sampled during 2014 to 2017 to investigate the incidences of both pathogens; incidences of the pathogens were compared by location, timing, and year. Incidence of A. alternata had been recorded starting in late June in every field every year, whereas incidence of $A$. solani started later in some of the fields. At the end of each growing season throughout the four years, the highest in-

southern Wisconsin. The highest incidence ( $100 \%$ every year) of A. alternata was observed in a field in Madison, an isolated potato field that was managed organically. Such distribution patterns could be a result of the different host ranges of the pathogens and abundance of inoculum in different geographic locations. In 2016, disease severity was correlated with the incidence of both pathogens $(P<0.0001$ to $P=0.0299)$, but in 2017 , disease severity was correlated with the incidence of $A$. solani in most of the fields $(P<0.0001$ to $P=0.0799)$. These findings suggest that both Alternaria spp. are important for considering disease management strategies in central and southern Wisconsin.
\end{abstract} cidence ( $100 \%$ most of the years) of $A$. solani was observed in a field in Plover, located in a concentrated potato production area of central Wisconsin, and a field in Arena, located in an isolated potato production area in
Keywords: disease severity, pathogen incidence, potato early blight, potato brown spot
Potato early blight caused by Alternaria solani is a perennial and destructive foliar fungal disease (Ding et al. 2019b; Leiminger and Hausladen 2012; Shtienberg et al. 1990). Infected leaves develop brown to black necrotic lesions with characteristic rings or bull's eyes, which reduce photosynthesis and eventually reduce quality and quantity of tubers worldwide (Leiminger and Hausladen 2012; Shtienberg et al. 1990; Tymon et al. 2016; Zheng et al. 2015). Brown spot, a second foliar disease caused by Alternaria alternata, has been identified as another sporadically destructive potato disease in recent years (Ding et al. 2019b; Fairchild et al. 2013; Zheng et al. 2015). The symptoms caused by A. alternata are typically small fleck-like lesions on potato leaves, and symptoms are typically smaller than those associated with $A$. solani. Both diseases are polycyclic, with initial conidial inoculum dispersed by wind and rain splash (van der Waals et al. 2001). Foliar symptoms are common in Wisconsin and are usually first observed in late June and persist to harvest. The pathogens overwinter on plant debris and may be carried in tubers as well (Secor and Gudmestad 1999). It is very common for the two Alternaria pathogens to co-occur, and symptoms of both diseases can be observed on the same leaves. However, despite the shared similarities, the emergence time and geographic distribution of potato-infecting $A$. alternata in Wisconsin were not well understood.

Potatoes are an important crop in Wisconsin, produced on 27,114 ha with a value of approximately $\$ 285$ million annually (USDA-NASS 2019), and the potential yield and quality losses caused by early blight

${ }^{\dagger}$ Corresponding author: A. J. Gevens; gevens@wisc.edu

Funding: This project was partially funded by the University of WisconsinMadison Hatch Formula grant program.

*The $\boldsymbol{e}$-Xtra logo stands for "electronic extra" and indicates that one supplementary table is published online.

The author(s) declare no conflict of interest.

Accepted for publication 29 June 2020.

C 2021 The American Phytopathological Society and brown spot are significant. In Wisconsin, potato production takes place across the entire state, but the most concentrated region is in central Wisconsin, often called the Central Sands or Golden Sands region because of the sandy loam soil condition. With prevailing warm and humid weather during the Wisconsin potato growing season, early blight and brown spot diseases are severe compared with more arid states (A. J. Gevens, personal communication). Currently no commercial potato cultivar is resistant to early blight or brown spot, so management relies primarily on regular fungicide applications. Because of the polycyclic nature of the diseases, starting from potato physiological day of 300 , growers typically apply fungicides on a weekly basis until vine-kill with a chemical desiccant, roughly 2 weeks before harvest to control the diseases (Pscheidt and Stevenson 1984). Such fungicide application results in a crop input cost of about $\$ 370 /$ ha annually (Jordan et al. 2014).

Most current fungicide programs target $A$. solani, presumably with the additional benefit of managing $A$. alternata because both pathogens are closely related and have similar life cycles (Agrios 2005). Fungicides commonly used include broad-spectrum base protectants such as chlorothalonil and mancozeb and single-site mode of action fungicides with some systemic activity, such as boscalid, a succinate dehydrogenase inhibitor, and azoxystrobin, a quinone outside inhibitor (QoI) fungicide (Jordan et al. 2014). However, despite the similarities of the pathogens, the two pathogen populations responded to the same fungicide programs differently (Ding et al. 2019a; Tymon et al. 2013). For example, according to Ding et al. (2019a), the $A$. solani population showed a high frequency of QoI resistance consistently, whereas the A. alternata population showed an increasing trend in the frequency of QoI resistance every season. Therefore, there is a great need to design targeted and prescriptive management of each pathogen to achieve better control of the diseases.

The significance of early blight caused by $A$. solani has long been recognized, whereas potato-infecting A. alternata has been understudied. Not all growers in Wisconsin are aware of brown spot infection, and therefore the time of emergence and distribution of $A$. alternata are unclear. Historically, A. alternata has been considered a minor disease in potatoes, but the contribution of the pathogen to foliar disease overall, compared with A. solani is unknown. However, such information is crucial in understanding the epidemiology of the disease and enhancing management of the disease in a more 
targeted manner (Carisse et al. 2008; Rekah et al. 1999). The objective of this study was to investigate the spatial distribution and timing of occurrence of Alternaria spp. causing diseases in potato fields to

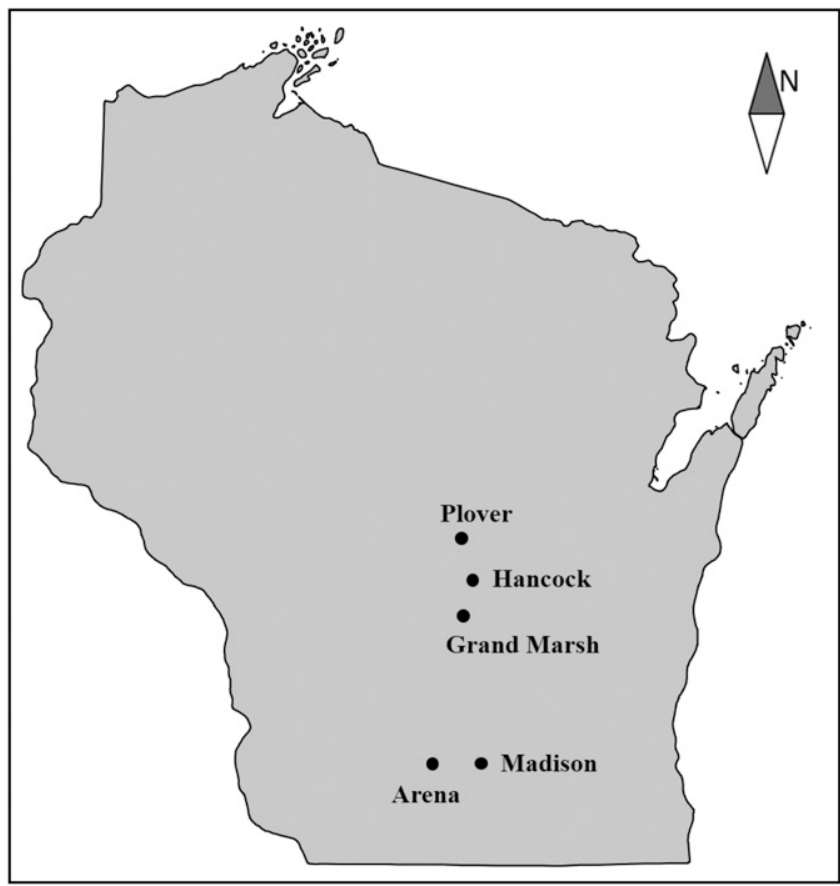

Fig. 1. Locations of potato fields in Wisconsin where diseased potato foliage were collected from 2014 to 2017.

Table 1. Year, location, and number of fields where Alternaria pathogen incidence and disease severity surveys were conducted

\begin{tabular}{cccccc}
\hline & \multicolumn{5}{c}{ No. of potato fields were sampled at each location in Wisconsin } \\
\cline { 2 - 6 } Year & Plover & Hancock & Grand Marsh & Arena & Madison \\
\hline 2014 & 1 & 2 & 1 & $-^{z}$ & 1 \\
2015 & 1 & 2 & 1 & 1 & 1 \\
2016 & 1 & 2 & 1 & 1 & 1 \\
2017 & 1 & 2 & 1 & 1 & 1 \\
\hline
\end{tabular}

${ }^{\mathrm{z}}$ Dash denotes lack of data. elucidate Alternaria species assemblage and significance in potato foliar diseases in Wisconsin.

\section{Materials and Methods}

Sample collection. Twenty-five symptomatic potato foliar samples were collected from each of six potato fields in Wisconsin (Fig. 1) in late June, late July, and late August from 2014 to 2017 (Table 1). Among the six fields, four were located in central Wisconsin (one field in Plover, two in Hancock, and one in Grand Marsh) and two were located in southern Wisconsin (one in Arena and one in Madison). Crop rotations occurred every year, so the closest potato fields to the fields studied the previous year were sampled. There was $\geq 6 \mathrm{~km}$ between the two fields in Hancock, and fields from different locations were $\geq 20 \mathrm{~km}$ from each other. All fields were commercial production fields with conventional management, with the exception of the field in Madison, which was a research field with certified organic management at West Madison Agricultural Research Station. Within each field, samples were collected from five sites: four corners of the field and one in the center of the field. For each site within a field, five plants were arbitrarily chosen for removal of foliar samples, and the plants were approximately $5 \mathrm{~m}$ apart from each other. For each plant, one compound leaf with lesions was collected as a sample (symptom may not be typical in early season).

Disease severity rating. In 2016 and 2017, disease severity ratings were taken while leaf samples were collected. The potato plants from which leaf samples were collected were rated 0 to $100 \%$ based on percent disease coverage. The area under the disease progress curves (AUDPC) was determined by trapezoidal integration and then converted into relative AUDPC (RAUDPC), the percentage of the maximum possible AUDPC for the whole period of the experiment (Pscheidt and Stevenson 1986; Weber and Jansky 2012).

Isolation and identification. For each sample, lesion margins were excised from each leaf, surface sterilized with $70 \%$ ethanol for $30 \mathrm{~s}$, and incubated on antibiotic-amended water agar (with $250 \mathrm{mg} / \mathrm{liter}$ ampicillin and $50 \mathrm{mg} / \mathrm{liter}$ rifampicin) to isolate the pathogens. Multiple lesions from each leaf were excised and cultured on individual Petri dishes, but only one conidium from all resulting colonies with the same conidial morphology was picked and subcultured onto clarified antibiotic-amended V8 juice agar (with $125 \mathrm{mg} /$ liter ampicillin and $50 \mathrm{mg} /$ liter rifampicin). To encourage sporulation, all cultures were incubated under $20 \mathrm{~h}$ light and $4 \mathrm{~h}$ dark at $21^{\circ} \mathrm{C}$ for 2 weeks in an incubator. Based on conidia morphology, isolates producing long conidia (70 to $90 \mu \mathrm{m}$ ) with long beaks (30 to $40 \mu \mathrm{m}$ ) were putatively identified
2014 A. solani

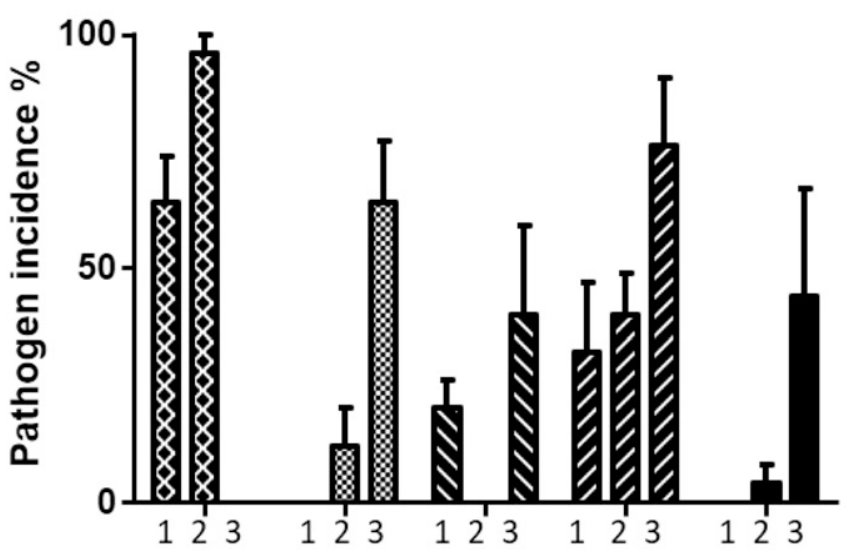

2014 A. alternata

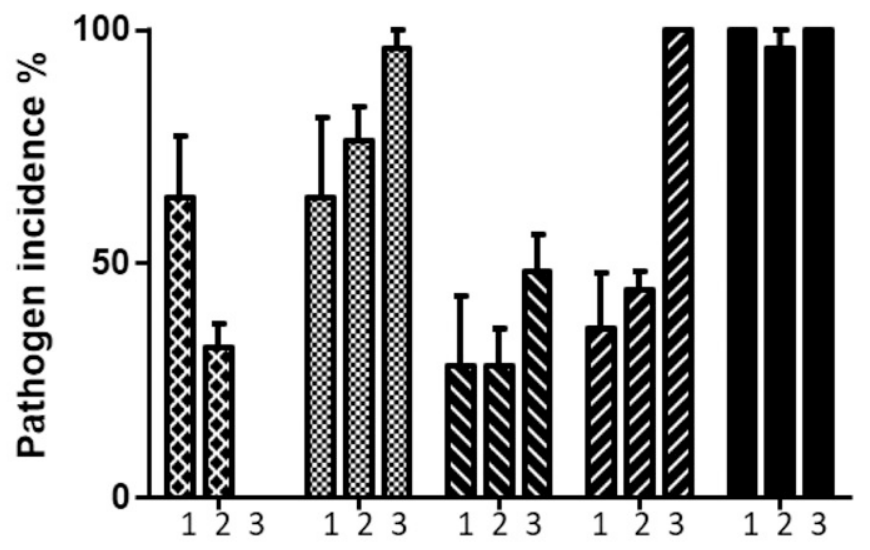

$$
1 \text { = June } 2 \text { = July } 3=\text { August }
$$

Fig. 2. Incidence of $A$. solani and A. alternata from potato fields in Plover, Grand Marsh, Hancock, and Madison in Wisconsin in June, July, and August 2014. Two fields were sampled in Hancock. The field in Plover was vine-killed early. 
as $A$. solani; isolates producing small conidia ( 25 to $35 \mu \mathrm{m}$ ) with short beaks ( 4 to $6 \mu \mathrm{m}$ ) were putatively identified as A. alternata.

For each Alternaria isolate, genomic DNA was extracted according to the protocol of Bok and Keller (2012). The Alt a 1 gene was amplified with primer pair Alt-for and Alt-rev (Hong et al. 2005). PCR products were purified with GenElute PCR Clean-Up Kit (Sigma-Aldrich) and sequenced at ProteinCT Biotech (Madison, WI). The sequences were aligned with reference sequences of $A$. solani and $A$. alternata to confirm the species identification.

Statistical analysis. Isolates of $A$. solani and A. alternata from each site in each field at each sampling time point were counted. The incidences of each pathogen in each field at each time were averaged from the five sites in each field. A multiple linear regression was conducted with location (field sampled), year, and location $\times$ year interaction with the PROC GLM procedure in SAS (SAS
Institute Inc., Cary, NC) to test their influence on the incidence of each pathogen at the end of each season. A Tukey test in PROC GLM in SAS was conducted to compare the incidence of each pathogen from different locations in each year. The same test was used to compare the incidences of each pathogen from 2014 to 2017 at each location. RAUDPC was calculated and compared between different fields across 2 years (2016 and 2017) with a Tukey test. All significant differences were based on a $P<0.05$ significance level.

A pairwise comparison of the two pathogen incidences was conducted via an ESTIMATE statement with PROC MIXED in SAS to examine which pathogen had a higher impact of the overall disease severity. Then the correlation coefficients between each Alternaria pathogen and the disease severity in 2016 and 2017 were calculated with Pearson correlation statistics in PROC CORR in SAS.
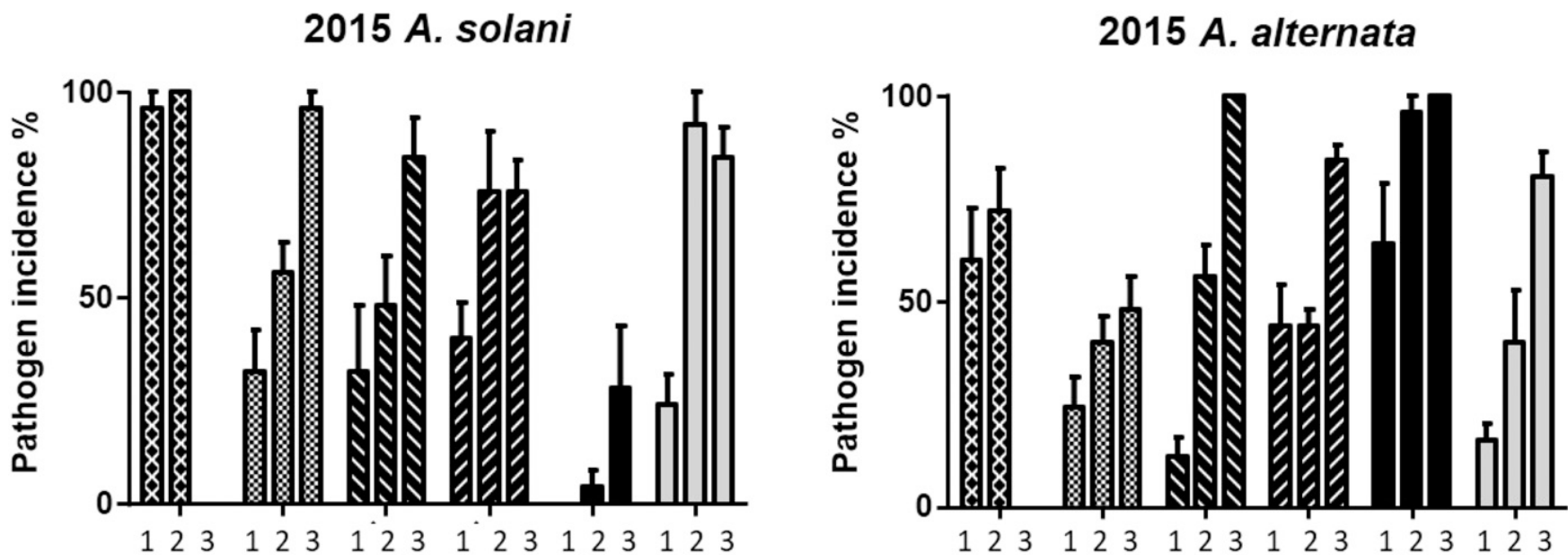

1 = June 2 = July 3 = August

XX] Plover Grand Marsh N Hancock I I/I Hancock II

Madison

Arena

Fig. 3. Incidence of $A$. solani and A. alternata from potato fields in Plover, Grand Marsh, Hancock, Madison, and Arena in Wisconsin in June, July, and August 2015. Two fields were sampled in Hancock. The field in Plover was vine-killed early.

2016 A. solani

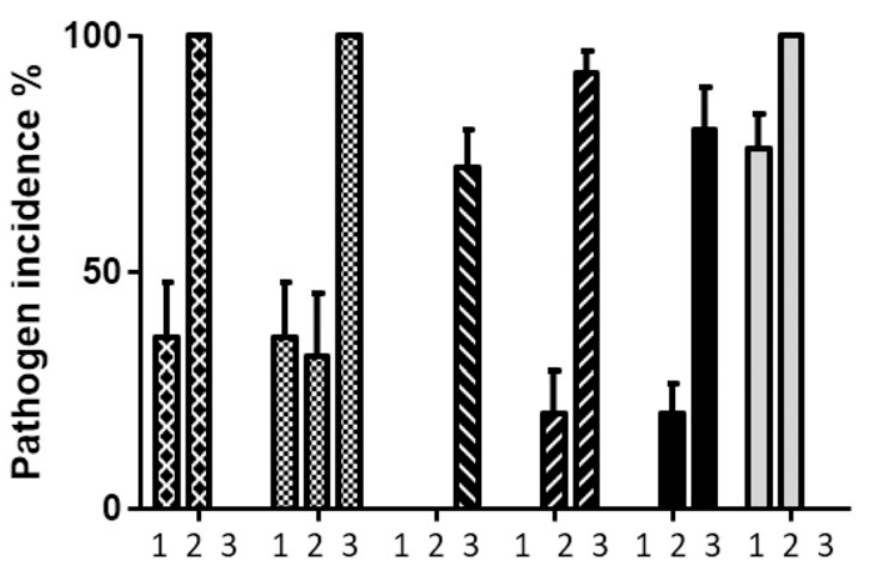

2016 A. alternata

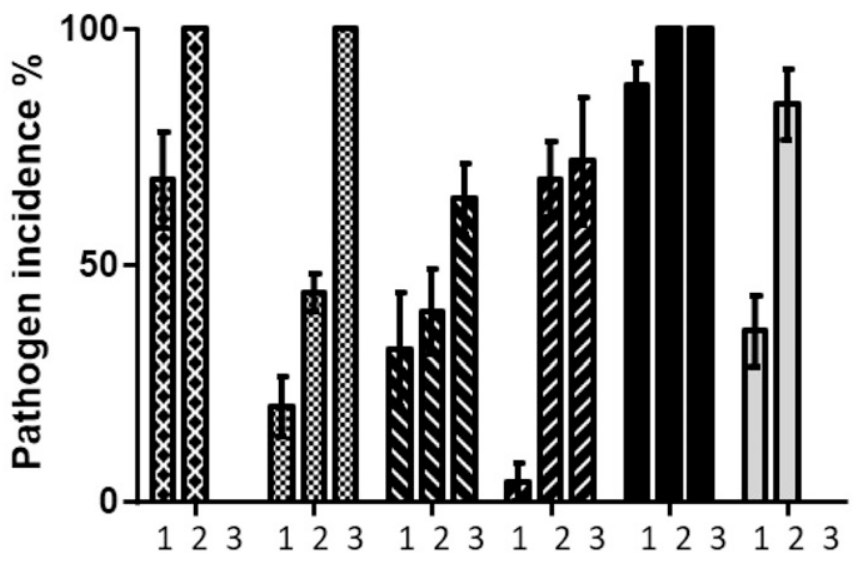

$$
1 \text { = June } 2 \text { = July } 3 \text { = August }
$$

$\mathbf{x}$ Plover Grand Marsh $\mathbf{N}$ Hancock I I/I Hancock II $\square$ Madison $\square$ Arena

Fig. 4. Incidence of A. solani and A. alternata from potato fields in Plover, Grand Marsh, Hancock, Madison, and Arena in Wisconsin in June, July, and August 2016. Two fields were sampled in Hancock. The fields in Plover and Arena were vine-killed early. 
After we controlled for year, time of the year, and location of sample collection, an ESTIMATE statement with PROC GLM was used to examine the influence of mean temperature and total precipitation of the month when sampling was conducted on the incidence of each pathogen. Archived weather data were obtained from Weather Underground (https://www.wunderground.com/) (Supplementary Table S1).

\section{Results}

Spatiotemporal distribution of Alternaria species. There was a general increasing trend in the incidence of $A$. solani and A. alternata from June to August of each year (Figs. 2, 3, 4, 5). A. alternata was detected in every sampling time point of every field, but $A$. solani was not detected until later during the season in some fields. In fields such as Hancock field I in 2016 (Fig. 4), Hancock field II in 2017, and the Madison field in 2017 (Fig. 5), the incidence of A. solani was detected only in the late August sampling.

Both year and location of the fields had significant influence on the incidences of $A$. solani $(P=0.0094)$ and A. alternata $(P<0.0001)$ based on the multiple linear regression. Specifically, the incidence of A. solani reached as high as $100 \%$ in Plover in late July, with the exception of 2014. By the time of vine-kill or at the end of the season, incidence of $A$. solani was usually high and reached $100 \%$ in most of the fields sampled. However, the field in Madison was an exception, because the incidence of $A$. solani started late and never reached $100 \%$. There is a high variation in the incidence of both pathogens at the end of potato growing season at different locations $(P 1$ in Table 2). The field in Madison had the highest $A$. alternata incidence (100\%) in all years from 2014 to 2017; both Plover and Arena had the highest $A$. solani incidence in all years from 2014 to 2017 and was as high as $100 \%$ in most years.

Dynamics of pathogen incidence from 2014 to 2017. The incidence of each pathogen at one location was compared from 2014 through 2017 ( $P 2$ in Table 2). During the four years, the incidence of $A$. solani in Plover, and the incidences of both pathogens in Hancock field II and Arena, were relatively stable (Table 2). In the field in Grand Marsh, the incidence of A. solani was lowest in 2014 and highest in 2016. In the field in Madison, the incidence of $A$. solani fluctuated from 2014 to 2017 . The incidence of $A$. alternata in the field in Grand Marsh and Hancock field I fluctuated from 2014 to 2017, whereas in the Hancock field II and the field in Madison, the incidence of A. alternata was stable throughout the four years.

\section{A. solani}

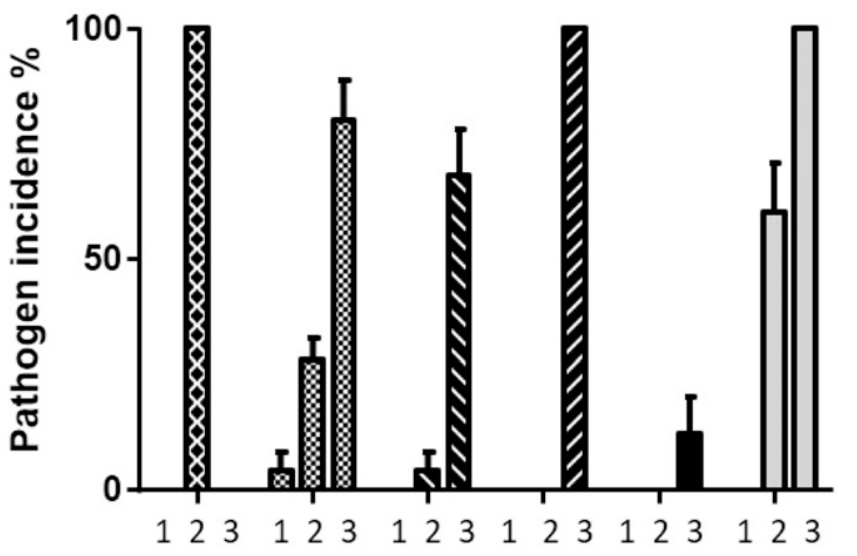

\section{A. alternata}

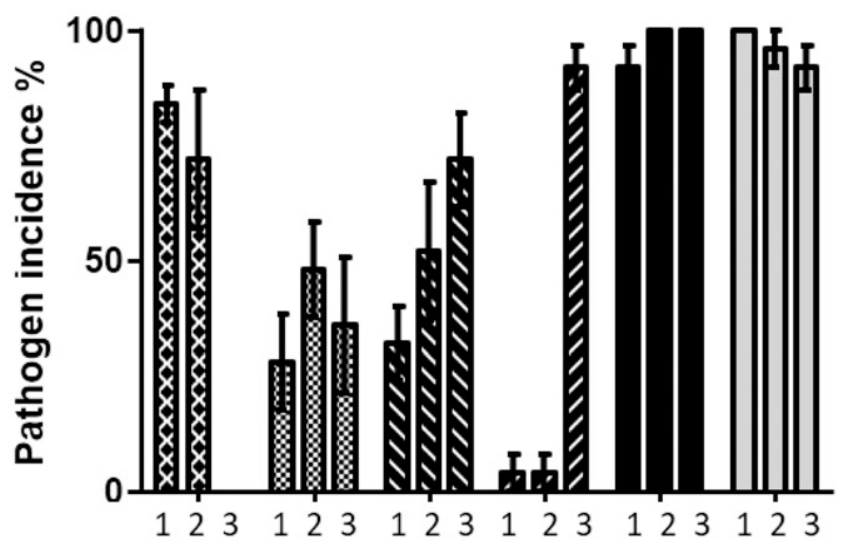

$$
1 \text { = June } 2 \text { = July } 3=\text { August }
$$

\section{$x \mathbf{x}$ Plover Grand Marsh $\mathbf{N}$ Hancock I I/2 Hancock II $\square$ Madison $\square$ Arena}

Fig. 5. Incidence of A. solani and A. alternata from potato fields in Plover, Grand Marsh, Hancock, Madison, and Arena in Wisconsin in June, July, and August in 2017. Two fields were sampled in Hancock. The field in Plover was vine-killed early.

Table 2. Comparison of A. alternata and A. solani incidence at different sampling locations in Wisconsin at the end of each potato growing season from 2014 to 2017

\begin{tabular}{|c|c|c|c|c|c|c|c|c|c|c|c|c|c|}
\hline & \multirow[b]{2}{*}{ Year } & \multicolumn{4}{|c|}{ Plover } & \multicolumn{4}{|c|}{ Grand Marsh } & \multicolumn{4}{|c|}{ Hancock I } \\
\hline & & Incidence (\%) & $\mathbf{S E}^{\mathbf{w}}$ & $P 1^{x}$ & $P 2^{\mathrm{y}}$ & Incidence (\%) & SE & $P 1$ & $\overline{P 2}$ & Incidence (\%) & SE & $P 1$ & $\overline{P 2}$ \\
\hline \multirow[t]{4}{*}{ A. alternata } & 2014 & 32 & 5 & $\mathrm{~b}$ & $\mathrm{~b}$ & 96 & 4 & $\mathrm{a}$ & $\mathrm{a}$ & 48 & 8 & $\mathrm{~b}$ & $\mathrm{~b}$ \\
\hline & 2015 & 72 & 10 & $\mathrm{bc}$ & $\mathrm{a}$ & 48 & 8 & $\mathrm{c}$ & $\mathrm{b}$ & 100 & 0 & $\mathrm{a}$ & $\mathrm{a}$ \\
\hline & 2016 & 100 & 0 & $\mathrm{a}$ & $\mathrm{a}$ & 100 & 0 & $\mathrm{a}$ & $\mathrm{a}$ & 64 & 7 & $\mathrm{~b}$ & $\mathrm{~b}$ \\
\hline & 2017 & 72 & 15 & $\mathrm{ab}$ & $\mathrm{a}$ & 36 & 15 & $\mathrm{~b}$ & $\mathrm{~b}$ & 72 & 10 & $a b$ & $a b$ \\
\hline \multirow[t]{5}{*}{ A. solani } & 2014 & 96 & 4 & $\mathrm{a}$ & $\mathrm{a}$ & 64 & 13 & $\mathrm{a}$ & $\mathrm{b}$ & 40 & 19 & $\mathrm{a}$ & $\mathrm{a}$ \\
\hline & 2015 & 100 & 0 & a & $\mathrm{a}$ & 96 & 4 & a & $a b$ & 84 & 10 & $\mathrm{a}$ & a \\
\hline & 2016 & 100 & 0 & $\mathrm{a}$ & $\mathrm{a}$ & 100 & 0 & a & $\mathrm{a}$ & 72 & 8 & $\mathrm{~b}$ & $\mathrm{a}$ \\
\hline & 2017 & 100 & 0 & $\mathrm{a}$ & $\mathrm{a}$ & 80 & 9 & $a b$ & $a b$ & 68 & 10 & $\mathrm{~b}$ & $\mathrm{a}$ \\
\hline & & & & & & & & & & \multicolumn{4}{|c|}{ (Continued on next page) } \\
\hline
\end{tabular}

\footnotetext{
w SE, standard error.

x $P 1$ denotes the significant difference of pathogen incidence between different fields in each year. The incidences were compared within each row, and the different letters in the " $P 1$ " columns in each row indicate significant differences at $\alpha=0.05$ based on the Tukey test.

y $P 2$ denotes the significant difference of pathogen incidence between different years in each field. The incidences were compared within each column for each pathogen, and the different letters in each " $P 2$ " column indicate significant differences at $\alpha=0.05$ based on the Tukey test.

z Dash denotes lack of data.
} 
Disease severity. Disease severity increased over each potato growing season (from June to August) (Fig. 6). According to the RAUDPC (Fig. 7) in 2016, the highest amount of disease was observed in the Madison field, and the lowest amount of disease was observed in field I at Hancock. However, in 2017 no difference in disease severity was observed between fields. From 2016 to 2017, disease severity increased in Hancock fields I and II but decreased in Madison.

Correlation between pathogen incidence and disease severity. A pairwise comparison via $t$ test in the ESTIMATE statement showed that the incidence of $A$. solani and A. alternata were similarly correlated with overall disease severity in 2016 (estimate $=0.0364$, $t=1.19, P=0.2407)$. However, in 2017 overall disease severity was more positively associated with the incidence of $A$. solani (estimate $=0.1349, t=4.76, P<0.0001)$. These results were consistent with the results of the Pearson correlation tests conducted between disease severity and the pathogen incidence for individual fields. In 2016, disease severity in all fields was correlated with the incidences of A. solani and A. alternata (Table 3). However, in 2017, in more than half of the fields, disease severity was not correlated with the incidence of $A$. alternata, and in the Madison field, disease severity was not correlated with the incidence of either pathogen. According to the $t$ test within the ESTIMATE statement (Table 4), the incidence of $A$. solani was positively correlated with mean temperature $(P=0.0279)$ and total precipitation $(P=0.0036)$, whereas the incidence of $A$. alternata was positively correlated only with total precipitation $(P=0.0541)$.

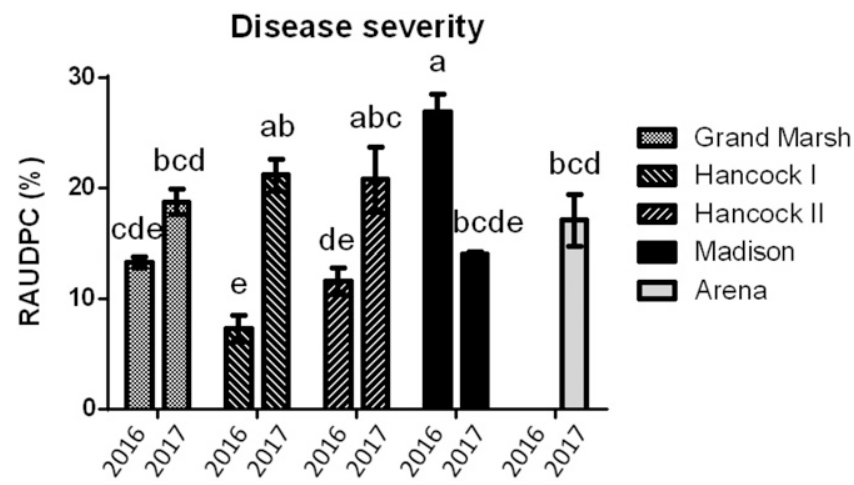

Fig. 7. Relative area under disease progress curve (RAUDPC) calculated based on the disease severity rating conducted from 2016 and 2017. Different letters above the columns indicate significant differences at $\alpha=0.05$ based on the Tukey test.

\section{6 disease severity}

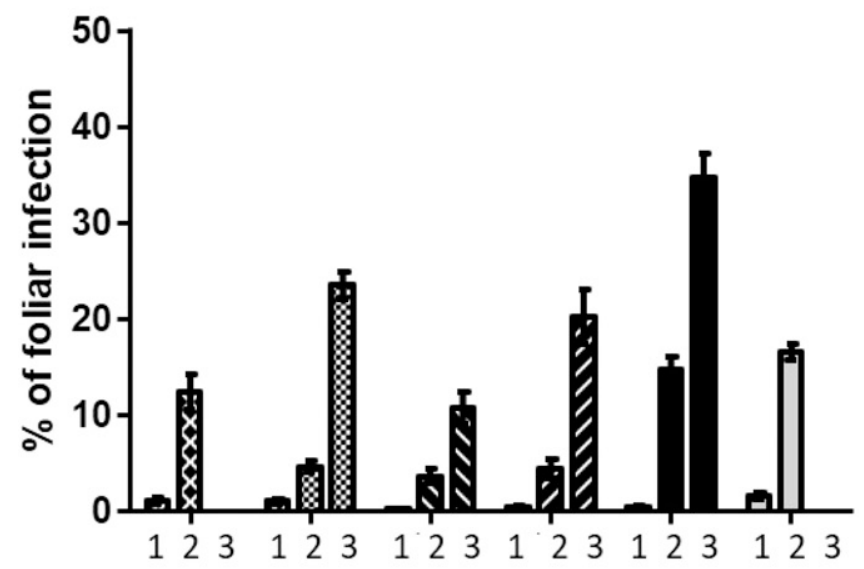

\section{7 disease severity}

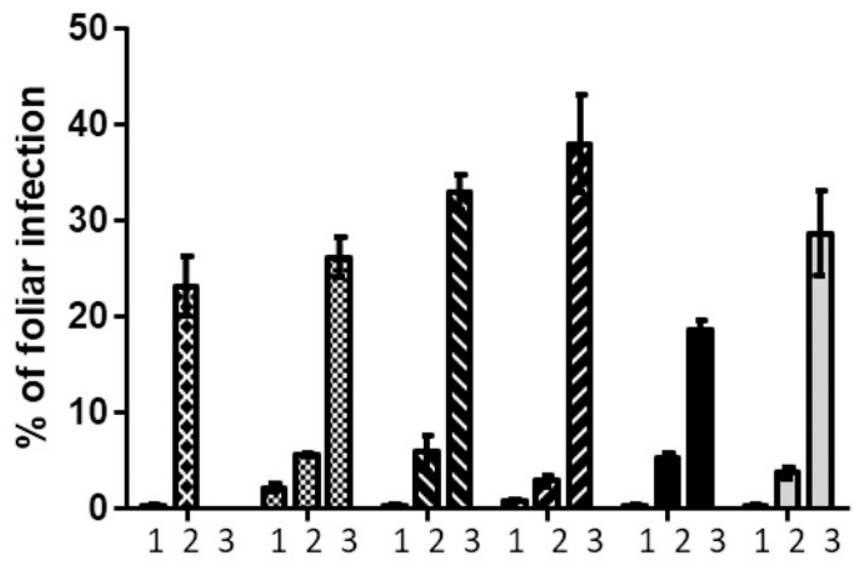

$$
1=\text { June } 2 \text { = July } 3 \text { = August }
$$

\section{$\mathbf{X X}$} Plover Grand Marsh NI Hancock I EIJ Hancock II Madison

Arena

Fig. 6. Disease severity of early blight caused by A. solani and brown spot caused by A. alternata from potato fields in Plover, Grand Marsh, Hancock, Madison, and Arena in June, July, and August in Wisconsin. Two fields were sampled in Hancock. The field in Plover was vine-killed early in both years, and the field in Arena was vine-killed early in 2016.

Table 2. (Continued from previous page)

\begin{tabular}{|c|c|c|c|c|c|c|c|c|c|c|c|}
\hline \multicolumn{4}{|c|}{ Hancock II } & \multicolumn{4}{|c|}{ Madison } & \multicolumn{4}{|c|}{ Arena } \\
\hline Incidence (\%) & SE & $P 1$ & $P 2$ & Incidence (\%) & SE & $P 1$ & $P 2$ & Incidence (\%) & SE & $P 1$ & $P 2$ \\
\hline 100 & 0 & $\mathrm{a}$ & $\mathrm{a}$ & 100 & 0 & $\mathrm{a}$ & $\mathrm{A}$ & $-{ }^{\mathrm{z}}$ & - & - & - \\
\hline 84 & 4 & $a b$ & $\mathrm{a}$ & 100 & 0 & $\mathrm{a}$ & A & 80 & 6 & $\mathrm{ab}$ & $\mathrm{a}$ \\
\hline 72 & 14 & $a b$ & $\mathrm{a}$ & 100 & 0 & $\mathrm{a}$ & A & 84 & 7 & $a b$ & $\mathrm{a}$ \\
\hline 92 & 5 & $\mathrm{a}$ & $\mathrm{a}$ & 100 & 0 & $\mathrm{a}$ & A & 92 & 5 & $\mathrm{a}$ & $\mathrm{a}$ \\
\hline 76 & 15 & $\mathrm{a}$ & $\mathrm{a}$ & 44 & 23 & $\mathrm{a}$ & $a b$ & - & - & - & - \\
\hline 76 & 7 & $\mathrm{a}$ & $\mathrm{a}$ & 28 & 15 & $b$ & B & 84 & 7 & $\mathrm{a}$ & $\mathrm{a}$ \\
\hline 92 & 5 & $a b$ & $\mathrm{a}$ & 80 & 9 & $\mathrm{ab}$ & $\mathrm{A}$ & 100 & 0 & $\mathrm{a}$ & $\mathrm{a}$ \\
\hline 100 & 0 & $\mathrm{a}$ & $\mathrm{a}$ & 12 & 8 & $\mathrm{c}$ & B & 100 & 0 & $\mathrm{a}$ & $\mathrm{a}$ \\
\hline
\end{tabular}




\section{Discussion}

Although A. solani and A. alternata are of the same genus and have similar life cycles, they showed different spatiotemporal distribution in six Wisconsin fields. A. alternata emerged as early as late June in all fields investigated, whereas the emergence of $A$. solani was later, as late as August in some locations. The incidences of both pathogens showed high variation in most fields, but there was a constantly high incidence of A. alternata in Madison from 2014 to 2017. The diseases co-occurred most of the time during the season, and $A$. solani contributed more than A. alternata to disease symptoms. However, A. alternata also contributed, though with variations between fields and years.

The first big difference in the spatiotemporal distribution of the two Alternaria pathogens was time of emergence, possibly because of the slightly different environmental conditions that favored each pathogen and susceptibility of the plants (Pscheidt and Stevenson 1984). Our study showed that during the growing season, temperature increased the incidence of $A$. solani but had little influence on the incidence of $A$. alternata. Therefore, the earlier emergence of A. alternata may be a result of a wider conducive temperature range of A. alternata. Later emergence of $A$. solani may be related to the maturity of the host plants, because $A$. solani is well known for infecting senescent plant tissue (Johanson and Thurston 1990). Incidentally, the incidence of $A$. solani in the field in Plover was high as early as late June. The potato production in this particular field was targeting the fresh market, and therefore potatoes were planted and matured and subsequently vine-killed early every year. Such early onset of the high incidence of A. solani in this field corresponded with the increased susceptibility of mature potato to early blight (Pelletier and Fry 1989).

Both A. solani and A. alternata were present in all of the fields and locations sampled; however, there were differences in their geographic distribution patterns. The difference with greatest significance was between the fields in Madison and Plover. The incidence of A. alternata was high in the Madison field, and the incidence of $A$. solani was high in Plover. Despite the difference in plant maturity levels as a result of different planting times, the two locations differ in terms of their surrounding fields. Plover is in the
Central Sands region, the area in central Wisconsin where potato production was highly concentrated. In Madison, there was no significant potato acreage, and at the research station there was great diversity of other plants such as tomato, onion, and beets. The early blight causal pathogen, A. solani, is a specific pathogen on potatoes and tomatoes (Thomma 2003). Therefore, we hypothesize that a higher volume of inoculum is expected in the Central Sands area than in the non-potato production area of Madison, whereas the brown spot causal pathogen, A. alternata, has a wide host range (Bashan et al. 1991; Gilchrist and Grogan 1976; Mazur et al. 2015; Ramjegathesh et al. 2011), so we hypothesize that the greater crop diversity at the research station in Madison provides a potential A. alternata reservoir and leads to more initial inoculum.

Incidences of both pathogens started low but became more evenly distributed as the season progressed. The incidence of each Alternaria sp. was unevenly distributed in the early season, as evidenced in the variation of pathogen incidence from the five sites in each field. Such an uneven distribution of pathogen incidence may be caused by patchy distribution of plant debris, which harbors initial inoculum (van der Waals et al. 2001). It may also be caused by Alternaria-infected seed potato pieces (Secor and Gudmestad 1999). Tuber infections by A. solani and A. alternata are rare but can be difficult to identify. Alternaria pathogens are not documented or subject to the certification processes for seed potatoes. Although both pathogens are suitable for wind dissemination (McCartney et al. 1993), A. solani conidia are not well known for long-distance wind dispersal (Ding et al. 2019c; Leiminger et al. 2014). In Wisconsin, growers use overhead irrigation systems, which were used in each of the commercial fields sampled in this study. Water splash and wind may facilitate short-distance dispersal, and therefore by the end of the season, the incidences of both pathogens were homogeneous in the fields (van der Waals et al. 2001).

A. solani is more virulent than A. alternata on potatoes and was observed as more dominant in disease symptoms as well (Ding et al. 2019b; Tymon et al. 2016). A higher incidence of $A$. solani was usually correlated with a higher disease severity. The incidence of $A$. alternata was correlated with disease severity in some cases. In 2016, incidences of both pathogens were correlated with the

Table 3. Pearson correlation coefficients between incidence of each pathogen and disease severity at each location in Wisconsin in 2016 and 2017

\begin{tabular}{|c|c|c|c|c|c|}
\hline & & \multicolumn{4}{|c|}{ Pearson correlation coefficients } \\
\hline & & $\begin{array}{c}\text { Incidence of } A . \text { alternata versus disease } \\
\text { severity }\end{array}$ & $P$ & $\begin{array}{c}\text { Incidence of } \boldsymbol{A} \text {. solani versus disease } \\
\text { severity }\end{array}$ & $\boldsymbol{P}$ \\
\hline \multirow{6}{*}{2016} & Plover & 0.68591 & 0.0262 & 0.83146 & 0.0016 \\
\hline & Grand Marsh & 0.94065 & $<0.0001$ & 0.82935 & $<0.0001$ \\
\hline & Hancock I & 0.62149 & 0.0117 & 0.86584 & $<0.0001$ \\
\hline & Hancock II & 0.6576 & 0.0063 & 0.91888 & $<0.0001$ \\
\hline & Madison & 0.55582 & 0.0299 & 0.93018 & $<0.0001$ \\
\hline & Arena & 0.84309 & 0.0011 & 0.75361 & 0.0094 \\
\hline \multirow[t]{6}{*}{2017} & Plover & -0.5489 & 0.1027 & 0.93374 & $<0.0001$ \\
\hline & Grand Marsh & -0.0327 & 0.9097 & 0.90605 & $<0.0001$ \\
\hline & Hancock I & 0.58465 & 0.0204 & 0.85594 & $<0.0001$ \\
\hline & Hancock II & 0.94876 & $<0.0001$ & 0.94302 & $<0.0001$ \\
\hline & Madison & 0.39477 & 0.1482 & 0.46643 & 0.0799 \\
\hline & Arena & -0.3108 & 0.2655 & 0.77385 & 0.0004 \\
\hline
\end{tabular}

Table 4. Estimation of the correlations between each pathogen incidence and the parameters of mean temperature and total precipitation based on the ESTIMATE statement with the PROC GLM procedure in SAS

\begin{tabular}{|c|c|c|c|c|c|}
\hline Pathogen & Parameter & Estimate & $\mathbf{S E}^{\mathbf{x}}$ & $t$ & $P$ \\
\hline \multirow[t]{2}{*}{ A. alternata } & Mean temperature ${ }^{\mathrm{y}}$ & 0.19 & 3.25 & 0.06 & 0.9537 \\
\hline & Precipitation $^{\mathrm{z}}$ & 0.12 & 0.06 & 1.94 & 0.0541 \\
\hline \multirow[t]{2}{*}{ A. solani } & Mean temperature & 11.31 & 5.10 & 2.22 & 0.0279 \\
\hline & Precipitation & 0.21 & 0.07 & 2.96 & 0.0036 \\
\hline
\end{tabular}

\footnotetext{
${ }^{\mathrm{x}} \mathrm{SE}$, standard error.

y Mean temperature indicates mean temperatures in June, July, and August at each sampling location in 2016 and 2017.

${ }^{\mathrm{z}}$ Precipitation indicates the total precipitation in June, July, and August at each sampling location in 2016 and 2017.
} 
disease severity; however, in 2017 disease severity was more tightly correlated with the incidence of $A$. solani. A. alternata has been considered an opportunistic pathogen on potatoes (Weber and Halterman 2012), which may become pathogenic or cause more infection when the environment is favorable, such as higher environmental humidity as a result of a heavier rainfall in 2016 compared with 2017. Although disease severity was correlated more with the incidence of $A$. solani, A. alternata also contributed to disease severity. The lack of correlation between disease severity and the incidence of $A$. alternata in 2017 was probably caused by the lack of increase in the disease incidence of A. alternata. Another explanation for the lack of correlation could be related to the typical symptom of brown spot. The incidence of A. alternata was high in fields such as Arena and Plover; however, the lesions caused by $A$. alternata were smaller than those caused by A. solani, and therefore they contributed less to the disease severity (Ding et al. 2019b; Tymon et al. 2016). The same may also explain the situation in Madison.

Despite the variation in Alternaria spp. incidence between fields and the disease severities they caused, there was an apparent increase in both pathogen incidences and disease severities from June to August. A variety of factors may lead to dramatic disease progression, and reduced management efficacy because of fungicide resistance in the pathogen populations could be a major factor. All commercial potato fields investigated in this study were on a weekly fungicide application schedule. It is possible that fungicide-resistant pathogen populations were widely distributed in these areas, given the frequent fungicide applications. A number of reports have shown the accumulation of resistance to several groups of fungicides including QoIs and succinate dehydrogenase inhibitor in Alternaria pathogen populations both in Wisconsin and worldwide (Bauske et al. 2018; Ding et al. 2019a; Fairchild et al. 2013; Leiminger et al. 2014; Rosenzweig et al. 2008; Tymon et al. 2013). However, fungicides are still a major way to control Alternaria spp. in potato. Therefore, there is an urgent need to revisit fungicide programs and take fungicide resistance management plans into consideration.

In summary, spatiotemporal distribution of potato-infectingAlternaria species in Wisconsin was investigated in this study, which may provide new insights into Alternaria disease management in potato production. By causing smaller lesions than $A$. solani, A. alternata contributed to disease severity overall. Therefore, management of A. alternata should not be neglected, especially in regions with high volumes of $A$. alternata inoculum historically. An earlier emergence of A. alternata than A. solani was observed in most of the fields in Wisconsin. Early and regular field scouting is necessary to provide evidence for early chemical applications for $A$. alternata control. The incidence of $A$. solani reached a high level sooner when the potatoes were planted earlier, as in the Plover field. Therefore, crop rotation and potato field deployment should take production style into consideration, such as not planting potato fields at different times adjacent to each other to prevent early planted potato fields becoming $A$. solani pathogen reservoirs.

\section{Acknowledgment}

We thank our grower collaborators for allowing us access to their fields for sample collections.

\section{Literature Cited}

Agrios, G. N. 2005. Plant Pathology. 5th ed. Elsevier Academic Press, Amsterdam, the Netherlands.

Bashan, Y., Levanony, H., and Or, R. 1991. Wild beets as an important inoculum source of Alternaria alternata, a cause of leaf-blight of cotton in Israel. Can. J. Bot. 69:2608-2615.

Bauske, M. J., Mallik, I., Yellareddygari, S. K. R., and Gudmestad, N. C. 2018. Spatial and temporal distribution of mutations conferring QoI and SDHI resistance in Alternaria solani across the United States. Plant Dis. 102: 349-358.

Bok, J. W., and Keller, N. P. 2012. Fast and easy method for construction of plasmid vectors using modified quick-change mutagenesis. Methods Mol. Biol. 944:163-174.
Carisse, O., Savary, S., and Willocquet, L. 2008. Spatiotemporal relationships between disease development and airborne inoculum in unmanaged and managed Botrytis leaf blight epidemics. Phytopathology 98:38-44.

Ding, S., Halterman, D. A., Meinholz, K., and Gevens, A. J. 2019a. Distribution and stability of quinone outside inhibitor fungicide resistance in populations of potato pathogenic Alternaria spp. in Wisconsin. Plant Dis. 103:2033-2040

Ding, S., Meinholz, K., Cleveland, K., Jordan, S. A., and Gevens, A. J. 2019b. Diversity and virulence of Alternaria spp. causing potato early blight and brown spot in Wisconsin. Phytopathology 109:436-445.

Ding, S., Rouse, D. I., Meinholz, K., and Gevens, A. J. 2019c. Aerial concentrations of pathogens causing early blight and brown spot within susceptible potato fields. Phytopathology 109:1425-1432.

Fairchild, K. L., Miles, T. D., and Wharton, P. S. 2013. Assessing fungicide resistance in populations of Alternaria in Idaho potato fields. Crop Prot. 49: 31-39.

Gilchrist, D. G., and Grogan, R. G. 1976. Production and nature of a host-specific toxin from Alternaria alternata f. sp. Lycopersici. Phytopathology 66: 165-171.

Hong, S. G., Cramer, R. A., Lawrence, C. B., and Pryor, B. M. 2005. Alt a 1 allergen homologs from Alternaria and related taxa: analysis of phylogenetic content and secondary structure. Fungal Genet. Biol. 42:119-129.

Johanson, A., and Thurston, H. D. 1990. The effect of cultivar maturity on the resistance of potatoes to early blight caused by Alternaria solani. Am. J. Potato Res. 67:615-623.

Jordan, S. A., Cleveland, K., and Gevens, A. J. 2014. Evaluation of foliar fungicides for control of potato early blight in Wisconsin, 2013. Proceedings of Wisconsin's Annual Potato Meeting 27:179-182.

Leiminger, J. H., Adolf, B., and Hausladen, H. 2014. Occurrence of the F129L mutation in Alternaria solani populations in Germany in response to QoI application, and its effect on sensitivity. Plant Pathol. 63:640-650.

Leiminger, J. H., and Hausladen, H. 2012. Early blight control in potato using disease-orientated threshold values. Plant Dis. 96:124-130.

Mazur, S., Kurzawinska, H., Nadziakiewicz, M., and Nawrocki, J. 2015. Redroot pigweed as a host for Alternaria alternata: the causal agent of Alternaria leaf blight in potato. Zemdirbyste 102:115-118.

McCartney, H. A., Schmechel, D., and Lacey, M. E. 1993. Aerodynamic diameter of conidia of Alternaria species. Plant Pathol. 42:280-286.

Pelletier, J. R., and Fry, W. E. 1989. Characterization of resistance to early blight in 3 potato cultivars: incubation period, lesion expansion rate, and spore production. Phytopathology 79:511-517.

Pscheidt, J. W., and Stevenson, W. R. 1984. The critical period for control of potato early blight, caused by Alternaria solani. Phytopathology 74:872.

Pscheidt, J. W., and Stevenson, W. R. 1986. Comparison of forecasting methods for control of potato early blight in Wisconsin. Plant Dis. 70 915-920.

Ramjegathesh, R., Ebenezar, E. G., and Muthusamy, M. 2011. Management of onion leaf blight by Alternaria alternata (FR.) Keissler by botanicals and bio-control agents. Plant Pathol. J. 10:192-196.

Rekah, Y., Shtienberg, D., and Katan, J. 1999. Spatial distribution and temporal development of Fusarium crown and root rot of tomato and pathogen dissemination in field soil. Phytopathology 89:831-839.

Rosenzweig, N., Atallah, Z. K., Olaya, G., and Stevenson, W. R. 2008 Evaluation of QoI fungicide application strategies for managing fungicide resistance and potato early blight epidemics in Wisconsin. Plant Dis. 92: 561-568.

Secor, G. A., and Gudmestad, N. C. 1999. Managing fungal diseases of potato Can. J. Plant Pathol. 21:213-221.

Shtienberg, D., Bergeron, S. N., Nicholson, A. G., Fry, W. E., and Ewing, E. E. 1990. Development and evaluation of a general model for yield loss assessment in potatoes. Phytopathology 80:466-472.

Thomma, B. P. H. J. 2003. Alternaria spp.: from general saprophyte to specific parasite. Mol. Plant Pathol. 4:225-236.

Tymon, L., Cummings, T. F., and Johnson, D. A. 2013. Fungicide resistance of two Alternaria species to azoxystrobin and boscalid in the Columbia Basin. Phytopathology 103:18.

Tymon, L. S., Cummings, T. F., and Johnson, D. A. 2016. Pathogenicity and aggressiveness of three Alternaria spp. on potato foliage in the US Northwest. Plant Dis. 100:797-801.

USDA NASS. 2019. Wisconsin agricultural statistics bulletin. https:// www.nass.usda.gov/Statistics_by_State/Wisconsin/Publications/Annual_ Statistical_Bulletin/. Last retrieved on Oct 8, 2020.

van der Waals, J. E., Korsten, L., and Aveling, T. A. S. 2001. A review of early blight of potato. Afr. Plant Prot. 7:91-102.

Weber, B., and Halterman, D. A. 2012. Analysis of genetic and pathogenic variation of Alternaria solani from a potato production region. Eur. J. Plant Pathol. 134:847-858

Weber, B. N., and Jansky, S. H. 2012. Resistance to Alternaria solani in hybrids between a Solanum tuberosum haploid and S. raphanifolium. Phytopathology 102:214-221.

Zheng, H. H., Zhao, J., Wang, T. Y., and Wu, X. H. 2015. Characterization of Alternaria species associated with potato foliar diseases in China. Plant Pathol. 64:425-433. 